\title{
IINS, FT-IR and DFT Study of the Internal Dynamics of $[4-\mathrm{apyH}]\left[\mathrm{SbCl}_{4}\right]$
}

\author{
K. HoŁderna-NatKaniec ${ }^{a, b, *}$, I. NatKanieC ${ }^{c, b}$, E. Mikuli $^{d}$, \\ J. Swiergiel ${ }^{a}$, V.D. KhavryUtChenko ${ }^{e}$ AND R. JAKUBAS ${ }^{f}$ \\ ${ }^{a}$ Institute of Physics, A. Mickiewicz University \\ Umultowska 85, 61-614 Poznań, Poland \\ ${ }^{b}$ Frank Laboratory of Neutron Physics, JINR, Dubna 141980, Russia \\ ${ }^{c} \mathrm{H}$. Niewodniczański Institute of Nuclear Physics, PAS \\ Radzikowskiego 152, 31-342 Kraków, Poland \\ ${ }^{d}$ Department of Chemical Physics, Jagiellonian University \\ Ingardena 3, 30-060 Kraków, Poland \\ ${ }^{e}$ Institute of Surface Chemistry, Ukrainian Academy of Science \\ Kiev, Ukraine \\ ${ }^{f}$ Faculty of Chemistry, University of Wrocław \\ Joliot-Curie 14, 50-383 Wrocław, Poland
}

Dedicated to Professor Jerzy Janik on the occasion of his 80th birthday

A combination of infrared and inelastic incoherent neutron scattering spectroscopies with the density functional theory and semi-empirical calculations was applied to propose an assignment of the vibrational spectra of 4-aminopyridine chloroantimonate(IV).

PACS numbers: 78.70.Nx, 33.20.Ea, 77.84.-s, 31.15.E-

\section{Introduction}

The subject of our investigation is an ionic-molecular crystal built of the organic 4-aminopyridine cation $[4 \text {-apyH }]^{+}$and the inorganic anion $\left[\mathrm{SbCl}_{4}\right]^{-}$. The crystal undergoes a few phase transitions at 240/240.5, 248.5/250, 270.5/271, $304 / 304 \mathrm{~K}$, respectively, on the cooling/heating runs. The symmetries of the monoclinic elementary cell in the subsequent phases numbered from $\mathrm{V}$ to I on heating are as follows: $P 2_{1} / c \leftrightarrow(C c) \leftrightarrow C c \leftrightarrow C 2 / c \leftrightarrow C 2 / c$ [1]. The crystal of

${ }^{*}$ corresponding author; e-mail: natkanie@amu.edu.pl 
[4- $\left.\mathrm{NH}_{2} \mathrm{C}_{5} \mathrm{H}_{4} \mathrm{NH}\right]\left[\mathrm{SbCl}_{4}\right]$ (abbreviation [4-apyH] $\left[\mathrm{SbCl}_{4}\right]$ ) shows ferroelectric properties in the temperature range from 240.5 to $271 \mathrm{~K}$. The crystalline structure is built of sheets of planar cations [4-apyH $]^{+}$separated by the chain of tetrahedral anions $\left[\mathrm{SbCl}_{4}\right]^{-}$. The $[4 \text {-apyH }]^{+}$cation is surrounded by a few anions and some close contact interactions of the hydrogen bridge type can be distinguished [2-8]. Although the hydrogen atoms of $\mathrm{NH}_{2}, \mathrm{CH}$, and $\mathrm{NH}^{+}$groups were in close contact with the anion, the strongest hydrogen bridge bond is formed between the imide $\left(\mathrm{NH}^{+}\right)$group and the anion. The strongest interaction is modelled in our study.

The molecular dynamics of the crystal was studied by the neutron and the infrared (IR) spectroscopies. The neutron vibrational spectra give the frequencies and intensities of all normal modes; their intensities were proportional to the displacement of each atom performing the vibrations and the incoherent cross-section for scattered nucleus (value of incoherent cross-section of proton is several times greater than that of nitrogen or carbon atoms, building the cation studied [9]). The IR intensity is proportional to the changes in the electrical dipole moment of the molecule.

To make the assignment of the subsequent bands in the spectra, the structure of the simple complex was optimised and the frequencies and intensities of the normal modes were calculated by the density functional theory (DFT) [10] and semi-empirical PM3 [11] methods. The interaction $\mathrm{N} 1-\mathrm{H}^{+} \ldots \mathrm{Cl}$ is the short-

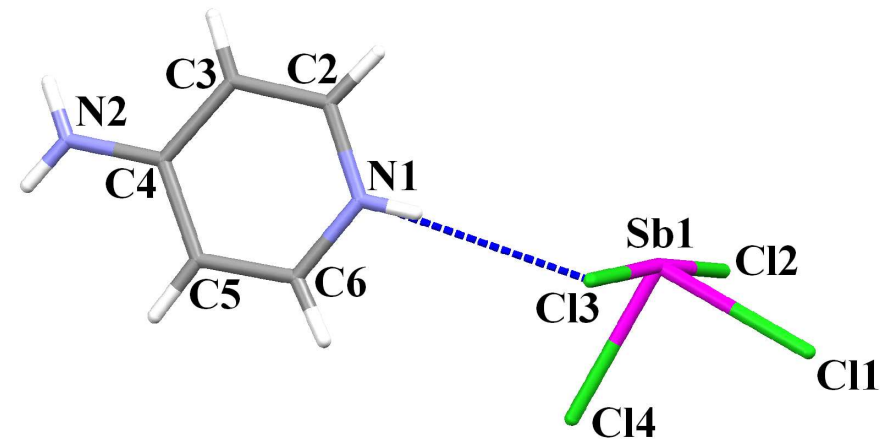

Fig. 1. Structure of the isolated molecule of $[4-\mathrm{apyH}]\left[\mathrm{SbCl}_{4}\right]$ with the atom numbering scheme [2-8].

est one, according to crystallographic data [2]. Therefore, the optimisation of the complex structure was performed, where this bridge is responsible for the interaction between the cation and the anion. The structure of the complex with the atom numbering system is presented in Fig. 1.

\section{Method}

The inelastic incoherent neutron scattering (IINS) spectra of the crystal studied were recorded as a function of the incident neutrons wavelength at different temperatures on a NERA-PR spectrometer in Dubna, co-working with a pulse 
reactor IBR-2 [12]. The Fourier transform infrared (FT-IR) absorption measurements were performed on a Bruker-EQUINOX 55 Fourier transformed infrared spectrometer.

The quantum mechanical calculation of the frequency and intensity of normal modes were performed by semi-empirical method as less time consuming, and by the density functional theory method using Gaussian 03 package [13].

\section{Results and discussion}

The IINS spectra of the crystal studied were recorded as a function of the wavelength of the incident neutrons at 20,240,260, and $290 \mathrm{~K}$. The IINS spectra were converted into the phonon density of states spectra $G_{\exp }(\nu)$ as shown in Fig. 2.

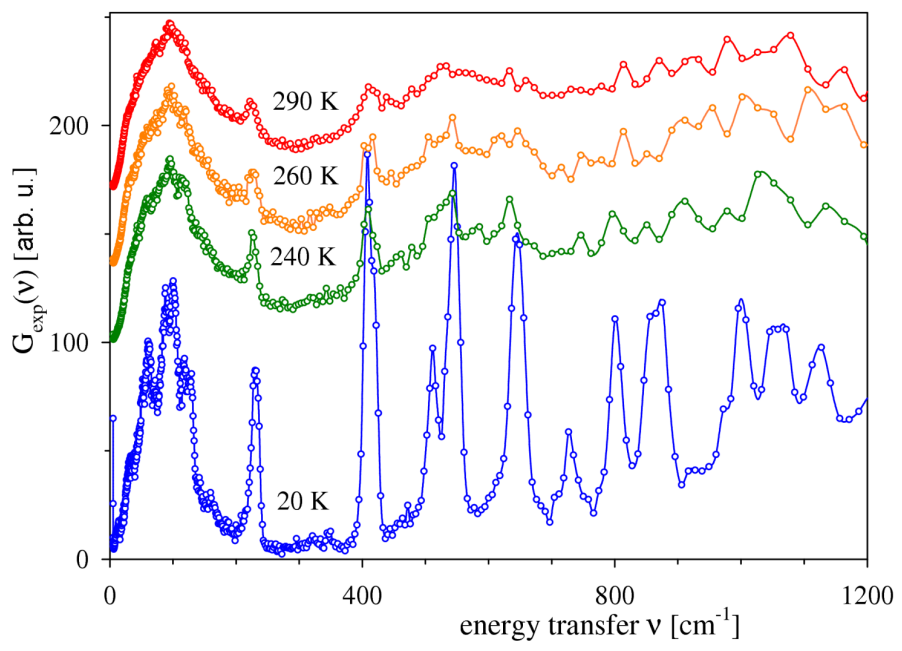

Fig. 2. Phonon density of state spectra of [4-apyH] $\left[\mathrm{SbCl}_{4}\right]$ obtained at different temperatures after transformation of the IINS spectra in one phonon scattering approximation, $G_{\exp }(\nu)$.

The low temperature $G_{\exp }(\nu)$ spectra show a well separated band above the energy gap of $240-350 \mathrm{~cm}^{-1}$, but below $700 \mathrm{~cm}^{-1}$. Its band width is close to the resolution power of the spectrometer. When the energy transfer increased, the intensity of selected bands as well as resolution power decreased $[14,9]$ according to the scattering law. In the low temperature $G_{\exp }(\nu)$ spectra one may distinguish well separated bands at 230.4, 407.8, 510.0, 544.8, $800.5 \mathrm{~cm}^{-1}$. Although on heating the intensity of the bands decreased, at room temperature the lattice branch and internal normal vibrational modes can be separated.

The FT-IR spectrum measured at $20 \mathrm{~K}$ (in nujol) is shown in the wave number range from 450 to $3500 \mathrm{~cm}^{-1}$ in Fig. 3. As in the range from 1750 to $2580 \mathrm{~cm}^{-1}$ no bands were observed, this part of the spectrum was neglected. 


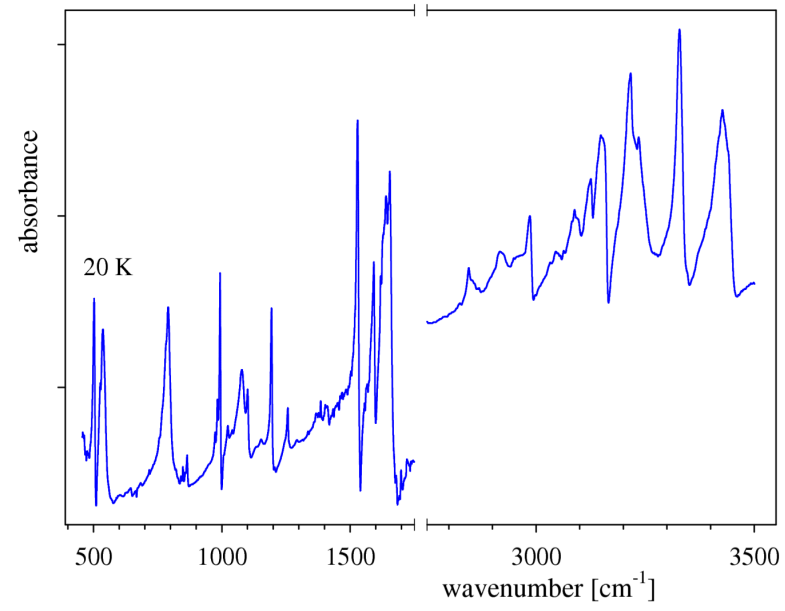

Fig. 3. FT-IR spectra of $\left[4\right.$-apyH] $\left[\mathrm{SbCl}_{4}\right]$ recorded in nujol at $20 \mathrm{~K}$.

The structures of the $[4 \text {-apyH }]^{+}$cation and the $[4$-apyH $]\left[\mathrm{SbCl}_{4}\right]$ complex were optimised by different quantum mechanical methods $[10,11,13]$. The structure of the isolated $[4 \text {-apyH }]^{+}$cation was optimised by the B3LYP/6-311G** method, while the structure of the complex — by the semi-empirical PM3 and B3LYP/LanL2Dz methods. The optimised structure of the complex obtained by the semi-empirical method is close to that determined by the X-ray studies [2]; the calculated angle $\mathrm{N} 1-\mathrm{Cl}-\mathrm{Sb}$ is $91^{\circ}$ while X-ray data give $93^{\circ}$. The bond length and internal angles of the skeleton of the optimised structures are collected in Table I. The data are also compared with the X-ray diffraction structure determined at $100 \mathrm{~K}[2]$.

The values of $R M S^{*}$ were calculated in order to compare the structure of the $[4 \text {-apyH }]^{+}$cation optimised by different methods with the X-ray data, according to the formula

$$
R M S=\sqrt{\frac{\sum\left(x_{\mathrm{cal}}-x_{\mathrm{exp}}\right)^{2}}{n}},
$$

where $x_{\text {cal }}$ and $x_{\text {exp }}$ are the calculated and experimental data, respectively. They are $0.008 \AA$ and $0.16^{\circ}$ for the bond length and internal angles, respectively. On the other hand, the $R M S$ were also calculated to compare the bond lengths and angles of the [4-apyH] $\left[\mathrm{SbCl}_{4}\right]$ complexes optimised by the B3LYP/LanL2Dz and PM3 methods with the experimental X-ray data; then the $R M S$ values are: $0.074 \AA$, $2.06^{\circ}$ and $0.112 \AA, 6.86^{\circ}$, respectively. Therefore, the optimisation of the skeleton structure of the studied complex of $[4$-apyH $]\left[\mathrm{SbCl}_{4}\right]$ by the DFT method gives a better approximation of its internal structure.

Then the frequencies and intensities of normal modes in the vibrational spectrum were calculated by quantum chemistry (QC) methods. Figure 4 shows a comparison of the low-temperature $G_{\exp }(\nu)$ spectrum and the calculated one. 
IINS, FT-IR and DFT Study of the Internal Dynamics ...

TABLE I

Geometry of $[4-\mathrm{apyH}]^{+}$and $[4-\mathrm{apyH}]\left[\mathrm{SbCl}_{4}\right]$ complex.

\begin{tabular}{|c|c|c|c|c|}
\hline \multirow[b]{3}{*}{ Bond } & \multicolumn{4}{|c|}{ Bond length } \\
\hline & \multicolumn{3}{|c|}{$\left[4\right.$-арyH] $\left[\mathrm{SbCl}_{4}\right][\AA]$} & \multirow{2}{*}{$\begin{array}{c}\frac{[4-\mathrm{apyH}]^{+}[\AA]}{\mathrm{B} 3 \mathrm{LYP} /} \\
6-311 \mathrm{G}^{* *}\end{array}$} \\
\hline & $\begin{array}{c}\text { X-ray } \\
\text { diffraction } \\
(100 \mathrm{~K})[2] \\
\end{array}$ & $\begin{array}{l}\text { B3LYP/ } \\
\text { LanL2Dz }\end{array}$ & PM3 & \\
\hline N1-C2 & 1.356 & 1.362 & 1.372 & 1.358 \\
\hline $\mathrm{C} 2-\mathrm{C} 3$ & 1.353 & 1.385 & 1.383 & 1.364 \\
\hline $\mathrm{C} 3-\mathrm{C} 4$ & 1.419 & 1.428 & 1.412 & 1.423 \\
\hline $\mathrm{C} 4-\mathrm{C} 5$ & 1.411 & 1.422 & 1.410 & 1.423 \\
\hline $\mathrm{C} 5-\mathrm{C} 6$ & 1.365 & 1.386 & 1.384 & 1.364 \\
\hline $\mathrm{C} 6-\mathrm{N} 1$ & 1.351 & 1.362 & 1.371 & 1.358 \\
\hline $\mathrm{N} 2-\mathrm{C} 4$ & 1.344 & 1.369 & 1.400 & 1.336 \\
\hline Sb1-Cl1 & 2.383 & 2.515 & 2.322 & \\
\hline $\mathrm{Sb} 1-\mathrm{Cl} 2$ & 2.683 & 2.815 & 2.336 & \\
\hline $\mathrm{Sb} 1-\mathrm{Cl} 3$ & 2.618 & 2.544 & 2.539 & \\
\hline Sb1-Cl4 & 2.378 & 2.512 & 2.342 & \\
\hline$R M S$ & & $\approx 0.074$ & $\approx 0.112$ & $R M S^{*} \approx 0.008$ \\
\hline \multirow[b]{3}{*}{ Internal angles } & \multicolumn{4}{|c|}{ Internal angles } \\
\hline & \multicolumn{3}{|c|}{$[4$-арyH $]\left[\mathrm{SbCl}_{4}\right]\left[{ }^{\circ}\right]$} & {$[4 \text {-apyH }]^{+}\left[^{\circ}\right]$} \\
\hline & $\begin{array}{c}\text { X-ray } \\
\text { diffraction } \\
(100 \mathrm{~K})[2]\end{array}$ & $\begin{array}{c}\text { B3LYP/ } \\
\text { LanL2Dz }\end{array}$ & PM3 & $\begin{array}{l}\text { B3LYP/ } \\
6-311 G^{* *}\end{array}$ \\
\hline N1-C2-C3 & 120.75 & 120.64 & 121.08 & 120.61 \\
\hline $\mathrm{C} 2-\mathrm{C} 3-\mathrm{C} 4$ & 119.85 & 119.63 & 119.55 & 119.95 \\
\hline C3-C4-C5 & 117.72 & 117.93 & 118.67 & 117.44 \\
\hline $\mathrm{C} 4-\mathrm{C} 5-\mathrm{C} 6$ & 119.76 & 119.57 & 119.67 & 119.95 \\
\hline $\mathrm{C} 5-\mathrm{C} 6-\mathrm{N} 1$ & 120.57 & 120.67 & 120.96 & 120.61 \\
\hline C6-N1-C2 & 121.32 & 121.55 & 120.06 & 121.43 \\
\hline $\mathrm{C} 3-\mathrm{C} 4-\mathrm{N} 2$ & 121.07 & 121.05 & 120.54 & 121.28 \\
\hline $\mathrm{C} 5-\mathrm{C} 4-\mathrm{N} 2$ & 121.21 & 121.02 & 120.61 & 121.28 \\
\hline Cl1-Sb1-Cl2 & 88.77 & 86.02 & 100.80 & \\
\hline Cl1-Sb1-Cl3 & 89.73 & 92.56 & 101.42 & \\
\hline Cl1-Sb1-Cl4 & 92.57 & 96.73 & 94.25 & \\
\hline $\mathrm{Cl2}-\mathrm{Sb} 1-\mathrm{Cl} 3$ & 173.93 & 172.76 & 157.26 & \\
\hline $\mathrm{Cl2-Sb1-Cl4}$ & 86.70 & 85.90 & 93.24 & \\
\hline Cl3-Sb1-Cl4 & 87.49 & 82.54 & 80.34 & \\
\hline$R M S$ & & $\approx 2.06$ & $\approx 6.86$ & $R M S^{*} \approx 0.16$ \\
\hline
\end{tabular}




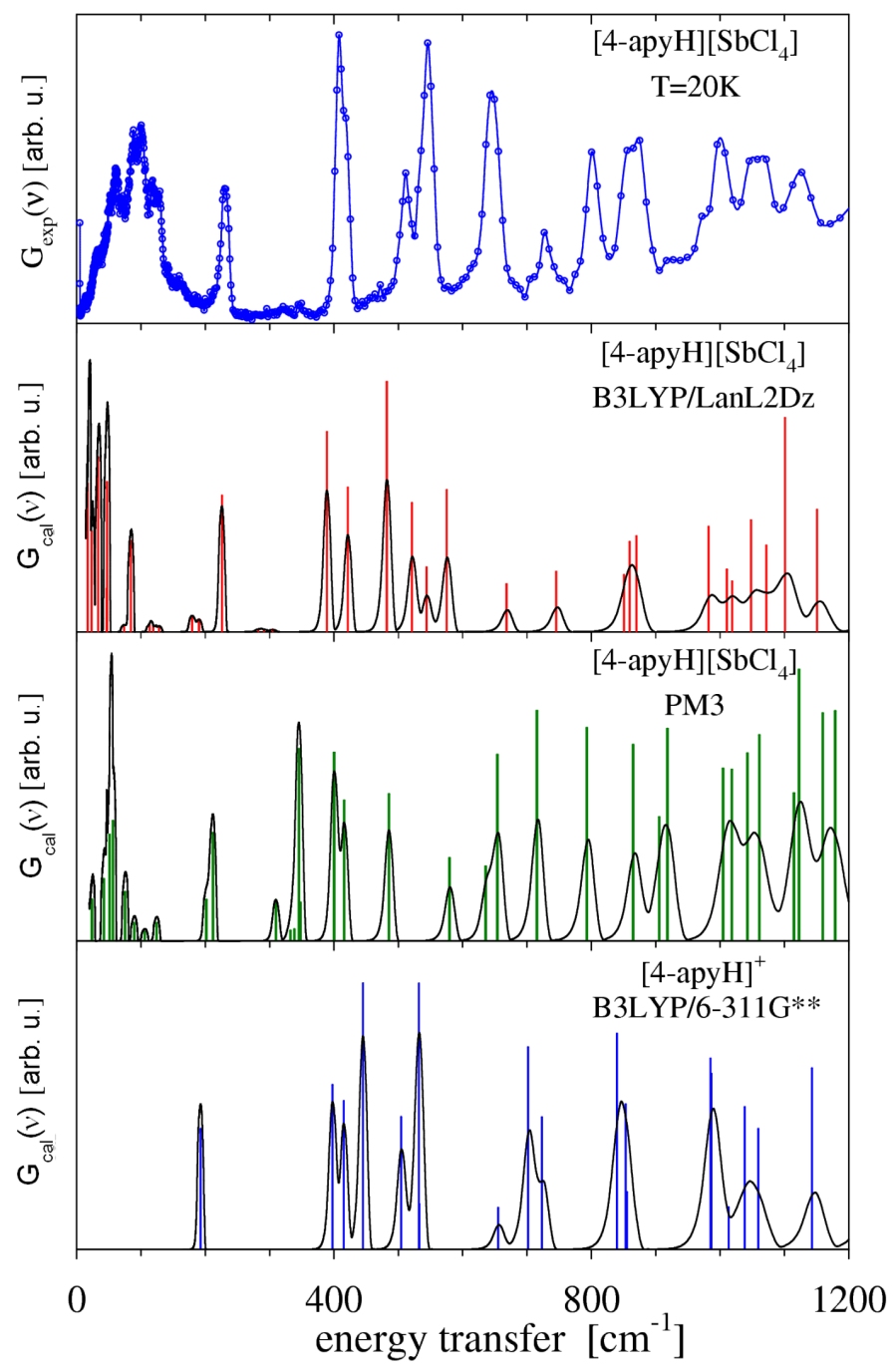

Fig. 4. The phonon density of state spectra of $\left[4\right.$-apyH] $\left[\mathrm{SbCl}_{4}\right]$ obtained at $20 \mathrm{~K}$ after transformation of the IINS spectra in one phonon scattering approximation $G_{\exp }(\nu)$. The $G_{\text {cal }}(\nu)$ spectra of $[4 \text {-apyH }]^{+}$calculated by DFT method B3LYP/6-311G**. The $G_{\text {cal }}(\nu)$ spectra of [4-apyH] $\left[\mathrm{SbCl}_{4}\right]$ calculated by B3LYP/LanL2Dz and semi-empirical PM3 methods; each calculated band is convoluted with the resolving power of the NERA spectrometer.

Table II collects the frequencies of the bands obtained by the neutron $G_{\exp }(\nu)$ and FT-IR spectroscopy at $20 \mathrm{~K}$, as well as the frequencies of normal modes calculated by the PM3 and B3LYP/LanL2Dz for the complex and also by B3LYP $/ 6-311 \mathrm{G}^{*}$ for the $[4$ apy-H] cation (columns: A - Frequencies of IINS at 
TABLE II

Comparison of the experimental and calculated frequencies of normal modes by different QC methods of [4-apyH $]\left[\mathrm{SbCl}_{4}\right]$ complex.

\begin{tabular}{|c|c|c|c|}
\hline A & $\mathrm{D}$ & $\mathrm{E}$ & $\begin{array}{c}\text { Assignment and potential energy } \\
\text { distribution (PED) [\%] }\end{array}$ \\
\hline & 17.3 & 23.7 & 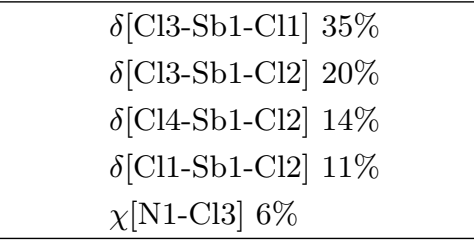 \\
\hline & 23.3 & 42.6 & $\begin{array}{l}\chi[\mathrm{Cl} 3-\mathrm{Sb} 1] 61 \% \\
\chi[\mathrm{N} 1-\mathrm{C} 2] 7 \% \\
\chi[\mathrm{N} 1-\mathrm{C} 6] 6 \% \\
\delta[\mathrm{Cl} 4-\mathrm{Sb} 1-\mathrm{Cl} 2] 5 \% \\
\end{array}$ \\
\hline 35.8 & 33.6 & 51.3 & $\begin{array}{l}\delta[\mathrm{C} 2-\mathrm{N} 1-\mathrm{Cl} 3] 29 \% \\
\delta[\mathrm{C} 6-\mathrm{N} 1-\mathrm{Cl} 3] 27 \% \\
\chi[\mathrm{Cl} 3-\mathrm{Sb} 1] 14 \% \\
\delta[\mathrm{N} 1-\mathrm{Cl} 3-\mathrm{Sb} 1] 5 \%\end{array}$ \\
\hline 52.7 & 46.6 & 56.4 & $\begin{array}{l}\chi[\mathrm{N} 1-\mathrm{Cl} 3] 69 \% \\
\chi[\mathrm{N} 1-\mathrm{C} 2] 9 \% \\
\chi[\mathrm{N} 1-\mathrm{C} 6] 7 \%\end{array}$ \\
\hline 60.8 & 47.3 & 75.5 & $\begin{array}{l}{[\text { [N1-Cl3-Sb1] } 25 \%} \\
\delta[\mathrm{Cl} 3-\mathrm{Sb} 1-\mathrm{Cl} 4] 19 \% \\
\delta[\mathrm{Cl} 4-\mathrm{Sb} 1-\mathrm{Cl} 2] 9 \% \\
\delta[\mathrm{C} 2-\mathrm{N} 1-\mathrm{Cl} 3] 7 \% \\
\delta[\mathrm{C} 6-\mathrm{N} 1-\mathrm{Cl} 3] 7 \%\end{array}$ \\
\hline 70.9 & 73.7 & 89.6 & $\begin{array}{l}\delta[\mathrm{Cl} 1-\mathrm{Sb} 1-\mathrm{Cl} 2] 32 \% \\
\delta[\mathrm{Cl} 4-\mathrm{Sb} 1-\mathrm{Cl} 2] 22 \% \\
\delta[\mathrm{Cl} 3-\mathrm{Sb} 1-\mathrm{Cl} 1] 14 \% \\
\delta[\mathrm{N} 1-\mathrm{Cl} 3-\mathrm{Sb} 1] 9 \%\end{array}$ \\
\hline 88.5 & 84.4 & 105.8 & $\delta[$ Cl4-Sb1-Cl1] $88 \%$ \\
\hline 100.5 & 113.5 & 124.4 & $\begin{array}{l}\delta[\mathrm{Cl} 4-\mathrm{Sb} 1-\mathrm{Cl} 2] 63 \% \\
\delta[\mathrm{Cl} 3-\mathrm{Sb} 1-\mathrm{Cl} 4] 21 \% \\
\end{array}$ \\
\hline 117.5 & 119.1 & & \\
\hline
\end{tabular}

$20 \mathrm{~K}\left[\mathrm{~cm}^{-1}\right], \mathrm{B}$ - Wave numbers of IR at $20 \mathrm{~K}\left[\mathrm{~cm}^{-1}\right], \mathrm{C}$ - Frequencies of $[4 \text {-apyH }]^{+}$by B3LYP $/ 6-311 \mathrm{G}^{* *}\left[\mathrm{~cm}^{-1}\right], \mathrm{D}$ - Frequencies of $\left[4\right.$-apyH] $\left[\mathrm{SbCl}_{4}\right]$ by B3LYP/LanL2Dz $\left[\mathrm{cm}^{-1}\right], \mathrm{E}-$ Frequencies of $[4-\mathrm{apyH}]\left[\mathrm{SbCl}_{4}\right]$ by PM3 $\left.\left[\mathrm{cm}^{-1}\right]\right)$. The assignment of the bands in the phonon density of state spectrum was predicted 
TABLE II (cont.)

\begin{tabular}{|c|c|c|c|c|}
\hline A & $\mathrm{C}$ & $\mathrm{D}$ & $\mathrm{E}$ & $\begin{array}{l}\text { Assignment } \\
\text { and PED [\%] }\end{array}$ \\
\hline 129.6 & & 128.0 & 201.6 & $\begin{array}{l}\nu[\mathrm{Cl} 3-\mathrm{Sb} 1] 56 \% \\
\nu[\mathrm{N} 1-\mathrm{Cl} 3] 10 \% \\
\delta[\mathrm{N} 1-\mathrm{Cl} 3-\mathrm{Sb} 1] 9 \%\end{array}$ \\
\hline 160 & & 179.4 & 211.9 & $\begin{array}{l}\chi[\mathrm{C} 3-\mathrm{C} 4] 31 \% \\
\chi[\mathrm{C} 4-\mathrm{C} 5] 31 \% \\
\rho[\mathrm{C} 3-\mathrm{C} 4-\mathrm{N} 2] 11 \% \\
\nu[\mathrm{Cl} 3-\mathrm{Sb} 1] 6 \% \\
\rho[\mathrm{C} 4-\mathrm{C} 5-\mathrm{C} 6] 6 \%\end{array}$ \\
\hline 230.4 & 192.7 & 190.2 & 309.9 & $\begin{array}{l}\nu[\mathrm{N} 1-\mathrm{Cl} 3] 50 \% \\
\nu[\mathrm{Cl} 3-\mathrm{Sb} 1] 11 \% \\
\nu[\mathrm{Sb} 1-\mathrm{Cl} 4] 9 \% \\
\nu[\mathrm{Sb} 1-\mathrm{Cl} 2] 8 \%\end{array}$ \\
\hline \multirow[t]{3}{*}{320.9} & & 225.9 & 332.5 & $\begin{array}{l}\nu[\mathrm{Sb} 1-\mathrm{Cl} 2] 83 \% \\
\nu[\mathrm{Cl} 3-\mathrm{Sb} 1] 9 \%\end{array}$ \\
\hline & & 282.7 & 338.4 & $\begin{array}{l}\nu[\mathrm{Sb} 1-\mathrm{Cl} 4] 80 \% \\
\nu[\mathrm{Sb} 1-\mathrm{Cl} 1] 11 \%\end{array}$ \\
\hline & & 291.1 & 345.5 & $\begin{array}{l}\chi[\mathrm{C} 4-\mathrm{N} 2] 58 \% \\
\chi[\mathrm{C} 2-\mathrm{C} 3] 13 \% \\
\chi[\mathrm{C} 6-\mathrm{C} 5] 12 \% \\
\end{array}$ \\
\hline 349.3 & & 304.7 & 347.7 & $\begin{array}{l}\nu[\mathrm{Sb} 1-\mathrm{Cl} 1] 83 \% \\
\nu[\mathrm{Sb} 1-\mathrm{Cl} 4] 9 \%\end{array}$ \\
\hline 407.8 & 397.7 & 389.2 & 400.2 & $\begin{array}{l}\chi[\mathrm{C} 2-\mathrm{C} 3] 32 \% \\
\chi[\mathrm{C} 6-\mathrm{C} 5] 31 \% \\
\chi[\mathrm{C} 4-\mathrm{N} 2] 10 \% \\
\chi[\mathrm{N} 1-\mathrm{C} 2] 8 \% \\
\chi[\mathrm{N} 1-\mathrm{C} 6] 5 \%\end{array}$ \\
\hline 418.3 & 415.3 & 421.6 & 415.9 & $\begin{array}{l}\delta[\mathrm{C} 3-\mathrm{C} 4-\mathrm{N} 2] 34 \% \\
\delta[\mathrm{N} 2-\mathrm{C} 4-\mathrm{C} 5] 34 \% \\
\chi[\mathrm{C} 6-\mathrm{C} 5] 7 \% \\
\chi[\mathrm{C} 2-\mathrm{C} 3] 7 \%\end{array}$ \\
\hline 471.5 & 445.1 & 482.2 & 485.2 & $\begin{array}{l}\rho[\mathrm{C} 3-\mathrm{C} 4-\mathrm{N} 2] 48 \% \\
\chi[\mathrm{N} 1-\mathrm{C} 6] 18 \% \\
\chi[\mathrm{N} 1-\mathrm{C} 2] 17 \% \\
\chi[\mathrm{C} 6-\mathrm{C} 5] 6 \%\end{array}$ \\
\hline
\end{tabular}

by the PM3 method. According to the results of the calculations, performed by the PM3 and B3LYP/6-311G** methods, the bands at the low neutron energy transfer (in the lattice branch) of the $G_{\exp }(\nu)$ spectrum can be interpreted as the 
TABLE II (cont.)

\begin{tabular}{c|c|c|c|c|l}
\hline \hline $\mathrm{A}$ & $\mathrm{B}$ & $\mathrm{C}$ & $\mathrm{D}$ & $\mathrm{E}$ & \multicolumn{1}{|c}{ Assignment } \\
and PED $[\%]$
\end{tabular}


TABLE II (cont.)

\begin{tabular}{|c|c|c|c|c|c|}
\hline $\mathrm{A}$ & B & $\mathrm{C}$ & $\mathrm{D}$ & $\mathrm{E}$ & $\begin{array}{l}\text { Assignment } \\
\text { and PED [\%] }\end{array}$ \\
\hline 925.7 & 974 & 985.2 & 982.3 & 1004.7 & $\chi[\mathrm{C} 2-\mathrm{C} 3] 29 \%$ \\
\hline \multirow{11}{*}{994.8} & 983 & 986.5 & & & $\rho[\mathrm{C} 2-\mathrm{C} 3-\mathrm{C} 4] 28 \%$ \\
\hline & 997 & & & & $\rho[\mathrm{N} 1-\mathrm{C} 2-\mathrm{C} 3] 25 \%$ \\
\hline & & & & & $\rho[\mathrm{N} 1-\mathrm{C} 6-\mathrm{H}] 33 \%$ \\
\hline & & & 1010.6 & 1018.3 & $\chi[\mathrm{C} 6-\mathrm{C} 5] 28 \%$ \\
\hline & & & & & $\rho[\mathrm{C} 4-\mathrm{C} 5-\mathrm{C} 6] 21 \%$ \\
\hline & & & & & $\chi[\mathrm{N} 1-\mathrm{C} 6] 8 \%$ \\
\hline & & & & & $\delta[\mathrm{N} 1-\mathrm{C} 2-\mathrm{H}] 18 \%$ \\
\hline & & & & & $\delta[\mathrm{N} 1-\mathrm{C} 6-\mathrm{H}] 11 \%$ \\
\hline & & 1013.3 & 1018.8 & 1042.5 & $\nu[\mathrm{C} 3-\mathrm{C} 4] 10 \%$ \\
\hline & & & & & $\delta[\mathrm{C} 3-\mathrm{C} 2-\mathrm{H}] 8 \%$ \\
\hline & & & & & $\delta[\mathrm{C} 4-\mathrm{C} 5-\mathrm{H}] 7 \%$ \\
\hline \multirow{8}{*}{$1059 \pm 10$} & & & & & $\delta[\mathrm{C} 4-\mathrm{N} 2-\mathrm{H}] 36 \%$ \\
\hline & 1025 & 1038.4 & 1048.2 & 1061.0 & $\delta[\mathrm{C} 4-\mathrm{N} 2-\mathrm{H}] 35 \%$ \\
\hline & & & & & $\nu[\mathrm{C} 4-\mathrm{C} 5] 8 \%$ \\
\hline & & & & & $\nu[\mathrm{C} 4-\mathrm{N} 2] 12 \%$ \\
\hline & & & & & $\delta[\mathrm{C} 3-\mathrm{C} 2-\mathrm{H}] 10 \%$ \\
\hline & 1079 & 1059.6 & 1072.1 & 1114.7 & $\nu[\mathrm{N} 1-\mathrm{C} 2] 9 \%$ \\
\hline & & & & & $\nu[\mathrm{N} 1-\mathrm{C} 6] 8 \%$ \\
\hline & & & & & $\delta[\mathrm{H}-\mathrm{C} 6-\mathrm{C} 5] 6 \%$ \\
\hline \multirow{5}{*}{$1126 \pm 10$} & \multirow{5}{*}{1101} & & & & $\delta[\mathrm{H}-\mathrm{C} 6-\mathrm{C} 5] 12 \%$ \\
\hline & & & & & $\delta[\mathrm{N} 1-\mathrm{C} 6-\mathrm{H}] 10 \%$ \\
\hline & & & 1101.0 & 1122.6 & $\delta[\mathrm{C} 2-\mathrm{C} 3-\mathrm{H}] 10 \%$ \\
\hline & & & & & $\delta[\mathrm{C} 4-\mathrm{C} 3-\mathrm{H}] 9 \%$ \\
\hline & & & & & $\delta[\mathrm{C} 6-\mathrm{C} 5-\mathrm{H}] 9 \%$ \\
\hline \multirow{5}{*}{$1218 \pm 15$} & & \multirow{5}{*}{1143.1} & \multirow{5}{*}{1150.8} & \multirow{5}{*}{1159.5} & $\delta[\mathrm{C} 6-\mathrm{C} 5-\mathrm{H}] 21 \%$ \\
\hline & & & & & $\delta[\mathrm{C} 4-\mathrm{C} 5-\mathrm{H}] 20 \%$ \\
\hline & & & & & $\delta[\mathrm{C} 2-\mathrm{C} 3-\mathrm{H}] 13 \%$ \\
\hline & & & & & $\delta[\mathrm{C} 4-\mathrm{C} 3-\mathrm{H}] 12 \%$ \\
\hline & & & & & $\delta[\mathrm{N} 1-\mathrm{C} 2-\mathrm{H}] 11 \%$ \\
\hline
\end{tabular}

deformation in-plane, torsional out-of-plane, or stretching vibrations of the anion $\left[\mathrm{SbCl}_{4}\right]^{-}$.

The band observed at $230.4 \mathrm{~cm}^{-1}$ can be interpreted according to the PM3 calculation results as the stretching vibrations $\nu$ [N1... Cl3], $\nu$ [Cl3-Sb1], $\nu$ [Sb1-Cl4], $\nu$ [Sb1-Cl2], but the first internal torsional out-of-plane mode of cation is given at $211.9 \mathrm{~cm}^{-1}$. The calculations performed by 
QC/B3LYP/LanL2Dz and B3LYP/6-311G** methods predict it at 190.2 and $192.7 \mathrm{~cm}^{-1}$, respectively. However, a comparison of the vibrational spectrum calculated for the isolated cation of $[4-\mathrm{apyH}]^{+}$and the experimental neutron scattering ones permits concluding that the strong band at $230 \mathrm{~cm}^{-1}$ observed in the lattice branch is an internal mode of the cation.

The most intense band in the low-temperature phonon density of state spectrum $G_{\exp }(\nu)$ of $[4-\operatorname{apyH}]\left[\mathrm{SbCl}_{4}\right]$ appears at the energy transfer of $407.8 \mathrm{~cm}^{-1}$. On the basis of the PM3 calculations the band at $400.2 \mathrm{~cm}^{-1}$ is assigned as the out-of-plane torsion of the 4-aminopyridinum cation: $\chi$ [C4-N2], $\chi$ [N1-C2], $\chi$ [N1-C6], $\chi$ [C2-C3], $\chi$ [C6-C5]. The DFT methods predict this band at 389.2 and $397.7 \mathrm{~cm}^{-1}$ for the complex, which is presented in Fig. 1, and for the isolated cation, respectively.

Another intense band is observed in the $G_{\exp }(\nu)$ spectrum at the energy transfer of $544.8 \mathrm{~cm}^{-1}$. The PM3 calculations predict a band at $635.8 \mathrm{~cm}^{-1}$ which may be interpreted as the deformation in-plane: $\delta$ [N1-C6-C5], $\delta[\mathrm{N} 1-$ $\mathrm{C} 2-\mathrm{C} 3], \delta$ [C4-C5-C6], $\delta[\mathrm{C} 2-\mathrm{C} 3-\mathrm{C} 4]$. According to this assignment, the intense $G_{\exp }(\nu)$ band in the low-temperature spectrum is related to the dynamics of the $\mathrm{N}(1) \mathrm{H}^{+}$group and therefore its intensity should decrease on heating. The B3LYP/ $6-311 \mathrm{G}^{* *}$ calculations predict it at 531.8 and $532.6 \mathrm{~cm}^{-1}$, while B3LYP/LanL2Dz - at $543.7 \mathrm{~cm}^{-1}$. Intermolecular interactions of hydrogen bridge bond type between the donor $-\mathrm{N}^{+} \mathrm{H}$ group and the acceptor take place in the crystal. They influence the internal structure of the cation; consequently, the frequencies of internal normal modes in the cation and in the complex are different.

The subsequent band appears at $645 \mathrm{~cm}^{-1}$. The PM3 calculation gives the normal mode at $715.5 \mathrm{~cm}^{-1}$ which may be assigned as deformational in-plane $\delta[\mathrm{C} 4-\mathrm{N} 2-\mathrm{H}], \delta[\mathrm{H}-\mathrm{N} 2-\mathrm{H}]$, out-of-plane torsion vibration of the 4-aminopiridinium cation $\chi[\mathrm{N} 1-\mathrm{C} 2]$ and out-of-plane vibration $\rho[\mathrm{C} 3-\mathrm{C} 4-\mathrm{N} 2]$. According to the B3LYP/LanL2Dz and B3LYP/6-311 $\mathrm{G}^{* *}$ calculations they are at $668.2 \mathrm{~cm}^{-1}$ and $665.2 \mathrm{~cm}^{-1}$, respectively.

Another intense band is observed in the $G_{\exp }(\nu)$ spectrum at the energy transfer $800.5 \mathrm{~cm}^{-1}$. On the basis of the PM3 calculations the band at $864.8 \mathrm{~cm}^{-1}$ is assigned as the out-of-plane vibration of the 4-aminopyridinum cation: $\rho[\mathrm{C} 2-$ C3-C4], $\rho$ [N1-C2-C3], $\rho$ [C4-C5-C6] and the torsional out-of-plane $\chi$ [N1-C2], $\chi$ [C3-C4]. The calculations for the $[4-\mathrm{apyH}]\left[\mathrm{SbCl}_{4}\right]$ complex and for the isolated cation predict this band at 850.9 and $839.8 \mathrm{~cm}^{-1}$, respectively.

The vibrational spectra calculated by QC methods also permit analysis of the normal modes in IR spectra. Figure 5 presents a comparison of the spectrum recorded experimentally at $20 \mathrm{~K}$ and that calculated by the B3LYP/LanL2Dz method. The frequencies of the observed normal modes (from neutron scattering as well as from IR data) and the unscaled calculated frequencies for 67 vibrational normal modes are plotted in Fig. 6. The slope of this dependence is 0.998. It may be noted that the deviations of the experimental frequencies from the calculated 


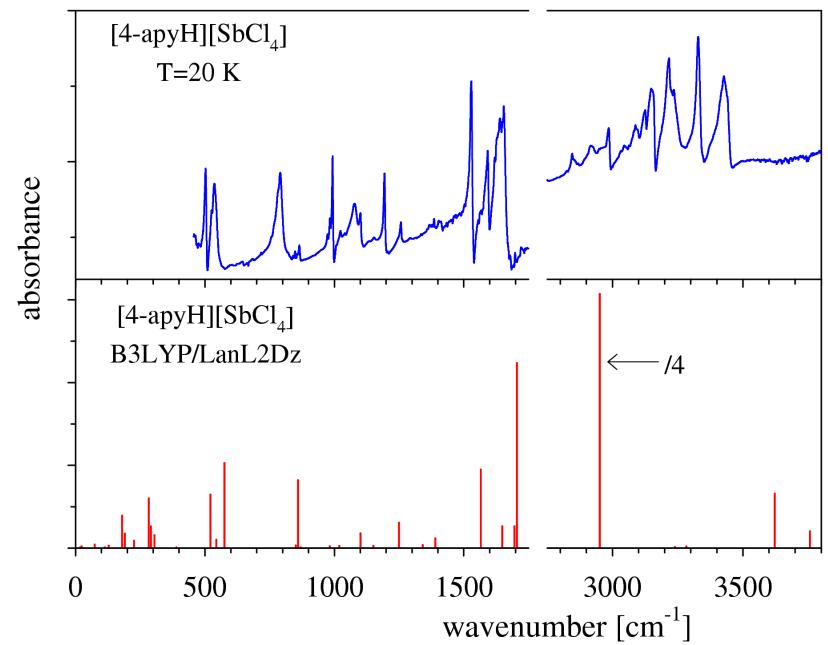

Fig. 5. Infrared absorbance of $[4-\mathrm{apyH}]\left[\mathrm{SbCl}_{4}\right]$ obtained at $20 \mathrm{~K}$ and bars calculated by QC method B3LYP/LanL2Dz.

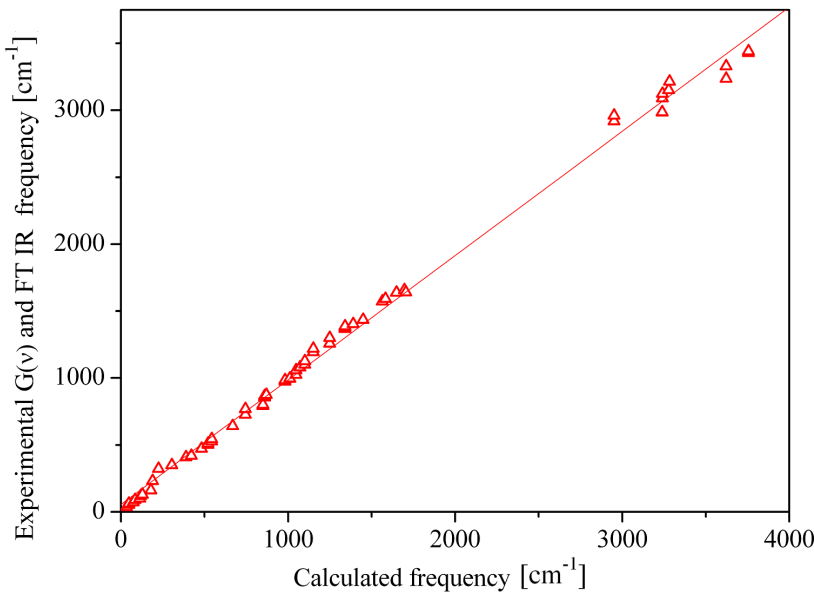

Fig. 6. Comparison of frequencies of normal modes obtained experimentally by neutron and IR methods (symbols). The lines were obtained after linear fit of both results.

ones are within several percents. The effect of vibrational anharmonicity seems to be negligible. The stretching modes are mainly red shifted, as shown in Figs. 5 and 6 , because of the hydrogen bridge interaction. Also these stretching vibrations $\nu[\mathrm{N}-\mathrm{H}]$ at $2986,3216,3328$, and $3429 \mathrm{~cm}^{-1}$ at $20 \mathrm{~K}$ undergo shifting on heating [15]. The observed changes in the intensity of $G_{\exp }(\nu)$ and the temperature shift of the IR bands at 502, 790, 1194, 2986, 3216, $3329 \mathrm{~cm}^{-1}$ [15] indicate an important role of the $\mathrm{N}-\mathrm{H}-\mathrm{Cl}$ interactions. 


\section{Summary}

Using the $a b$ initio and semi-empirical calculations the influence of the $\mathrm{N} 1-\mathrm{H} . \ldots \mathrm{Cl}(3)$ hydrogen bridge interactions in $[4-\mathrm{apyH}]\left[\mathrm{SbCl}_{4}\right]$ on the vibrational spectra has been studied. According to the X-ray data, the bond is nearly linear, the characteristic $\mathrm{N} 1-\mathrm{H} . . \mathrm{Cl}$ angle is $172.39^{\circ}$, and its length is $3.267 \AA$ [2]. The geometries of the complex, the strongest interaction in it and vibrational frequencies have been obtained. The semi-empirical calculations give the structure of the complex analysed close to that following from the X-ray diffraction study. The influence of the hydrogen bridge on the internal structure and the vibrational spec$\operatorname{tra}\left(G_{\exp }(\nu)\right.$ and FT-IR absorbance) has been determined. The observed decrease in the intensity of selected normal modes in the $G_{\exp }(\nu)$ spectra on heating has been interpreted as corresponding to the increasing dynamics of protons.

\section{Acknowledgments}

Financial support under the grant of the Polish Plenipotentiary at JINR is gratefully acknowledged by the authors. The calculations were performed at the PCSC in Poznań.

\section{References}

[1] R. Jakubas, Z. Ciunik, G. Bator, Phys. Rev. B 67, 024103 (2003).

[2] CCDC No. 185826-185828. Copies of this information may be obtained free of charge from the Director, CCDC, 12 UNION Road, Cambridge CB2 1EZ, UK (e-mail: deposit@ccdc.cam.ac.uk or http:////www.ccdc.cam.ac.uk).

[3] F.H. Allen, Acta Crystallogr. B 58, 380 (2002).

[4] I.J. Bruno, J.C. Cole, P.R. Edgington, M. Kessler, C.F. Macrae, P. McCabe, J. Pearson, R. Taylor, Acta Crystallogr. B 58, 389 (2002).

[5] C.F. Macrae, P.R. Edgington, P. McCabe, E. Pidcock, G.P. Shields, R. Taylor, M. Towler, J. van de Streek, J. Appl. Crystallogr. 39, 453 (2006).

[6] I.J. Bruno, J. Cole, J.P.M. Lommerse, R.S. Rowland, R. Taylor, M. Verdonk, J. Comput. Aid. Mol. Des. 11, 525 (1997).

[7] I.J. Bruno, J.C. Cole, M. Kessler, J. Luo, W.D.S. Motherwell, L.H. Purkis, B.R. Smith, R. Taylor, R.I. Cooper, S.E. Harris, A.G. Orpen, J. Chem. Inf. Comp. Sci. 44, 2133 (2004).

[8] M.L. Verdonk, J.C. Cole, R. Taylor, J. Mol. Biol. 289, 1093 (1999).

[9] Neutron Data Booklet, Eds. A.J. Dianoux, G. Lander, ILL Neutrons for Sciences, Grenoble 2003.

[10] A.D. Becke, J. Chem. Phys. 97, 9173 (1992); J. Chem. Phys. 98, 5648 (1993); C. Lee, W. Yang, R.G. Parr, Phys. Rev. B 37, 785 (1988).

[11] I.J.P. Stewart, J. Mol. Model. 10, 155 (2004); J. Comp. Chem. 12, 320 (1991), ibid. 10, 209 (1989); 10, 221 (1989); V.D. Khavryutchenko, COSPECO Complex Program for Vibrational Spectroscopy, Institute of Surface Chemistry, Ukrainian Academy of Sciences, Kiev 1990. 
[12] I. Natkaniec, S.I. Bragin, J. Brankowski, J. Mayer, in Proc. ICANS XII Meeting, Abington 1993, Vol. I, 1994, RAL Report, 94-025, I, p. 89.

[13] M.J. Frish, G.W. Trucks, H.B. Schlegel, G.E. Scuseria, M.A. Robb, J.R. Cheeseman, V.G. Zakrzewski, J.A. Montgomery, R.E. Stratmann, J.C. Burant, S. Dapprich, J.M. Millam, A.D. Daniels, K.N. Kudin, M.C. Strain, O. Farkas, J. Tomasi, V. Barone, M. Cossi, R. Cammi, B. Mennucci, C. Pomeli, C. Adamo, S. Clifford, J. Ochterski, G.A. Patersson, P.Y. Ayala, Q. Cui, K. Morokuma, D.K. Malick, A.D. Rabuck, K. Raghavachari, J.B. Foresman, J. Cioslowski, J.V. Ortiz, B.B. Stefanov, G. Liu, A. Liashenko, P. Piskorz, I. Komaromi, R. Gomperts, R.L. Martin, D.J. Fox, T. Keith, M.A. Al-laham, C.Y. Peng, A. Nanayakkara, C. Gonzalez, M. Challacombe, P.M.W. Gill, B.G. Johnson, W. Chen, M.W. Wong, J.L. Andres, M. Head-Gordon, E.S. Replogle, J.A. Pople, GAUSSIAN 03, Gaussian, Inc., Pittsburgh PA, 2003.

[14] W.J. Kazimirov, I. Natkaniec, Preprint P14-2003-48 JINR, Dubna 2003.

[15] K. Holderna-Natkaniec, I. Natkaniec, J. Swiergiel, unpublished results; J. Swiergiel, Ph.D. Thesis, IF UAM, Poznań 2007. 